\title{
Perovskite-Based Tandem/Multi-junction Solar Cells
}

\author{
H. A. El-Demsisy*, W. S. Selmy* \\ Department of Basic Engineering Science, Faculty of Engineering, Benha University, Benha, Egypt \\ *Corresponding author: E-mail: noda_dems@yahoo.com, walidsol@yahoo.com
}

Received 2 May 2021

Revised 19 June 2021

Accepted for publication 13 November 2021

Published online 13 November 2021

\section{Abstract}

Nowadays, with all their different forms, tandem cells are considered on top of the modern fields that many researchers try to explore all over the world. Both theoretical studies and applied technologies are struggling to realize the theoretical limit of the single-cell efficiency $(\sim 30 \%)$. Many kinds of tandem cells can be gathered together in different categories. Concerning the materials used, they are classified into organic, inorganic, and hybrid. But sometimes, they are classified, focusing on the connections used for sub-cells - stacked, optical splitting, or monolithic. Halide perovskite-based solar cells have acquired great significance in recent years. They gained a major interest because of their cheap and simple manufacturing as well as fast efficiency improvements. All these advantages have already met those of the industrially prevailing multi-crystalline silicon. Integration of perovskite absorber materials into multi-junction cells encourages researchers to exceed the limits of siliconbased technology and run after higher power transforming efficiencies. Layering many absorbers solar junctions stacked one above the other helped in the absorption process throughout the solar spectrum, hence, more energy could be obtained from sunlight. Two qualities caused perovskites to become the ideal candidates: First, the availability of adjusting the energy gap of perovskite materials to a great extent. Second, the capability to produce high open-circuit voltages from wide-bandgap absorbers. Perovskites could be used combined with or as an alternative for silicon (Si) in photovoltaic technologies. Those technologies were used practically and could be collected in architectures of hybrid tandems or layered in all multi-junction perovskite cells. In this review, many opportunities for perovskite multi-junction cells were tested in an attempt to find out new developments via inspecting possibilities.

Keywords: Perovskite; Tandem; Multi-junction; Photovoltaic.

\section{Introduction}

It is a must for our planet to seek clean renewable energy resources replacing fossil fuels. The harm caused by greenhouse gas releases is unimaginable. Solar energy, surely, is one of the most influential energy resources and solar cells are the prominent model to embody solar energy usage. Consequently, and owing to the fact that solar energy is extremely beneficial, photovoltaic appliances with high conversion energy are demanded. A photovoltaic (PV) solar cell is a solid-state semiconductor device that converts sunlight to electricity without any greenhouse gases, emissions, or pollution during operation [1]. Silicon solar cells are kept in the control of a great proportion in the market [2] since silicon is bountiful, stable, non-toxic, and plays an important role in semiconductors and their development. Suddenly, technology interfered, and measure units became sturdy with low costs of manufacturing. Studies admitted that the silicon solar cells had great qualities, but disadvantages revealed in inadequate absorption and limiting efficiency. So there had to be a different technique followed to evolve its performance. In the last years, efficiency in perovskite applied science has clear advance. Perovskite materials had a hearable effect in the photovoltaic technology as it showed to meet the needed qualities such as high absorption coefficient $\left(4.3206 \times 10^{5} \mathrm{~cm}^{-1}\right.$ at $\left.413 \mathrm{~nm}\right)$ [3], high dielectric constant [4], and inconstant energy gap (1.51$3.0 \mathrm{eV}$ ) [4]. Solar cells, based on perovskites, are devices invented to work upon a very simple idea. This 
achieves lower manufacturing costs and gives the ability to face silicon technology in the predictable future [5]. A model of perovskite solar cell consisted of five various layers involving anti-reflective layer, transparent conductive oxides (TCO) layer, electron and hole transport layer (ETL and HTL), and rear metal contact.

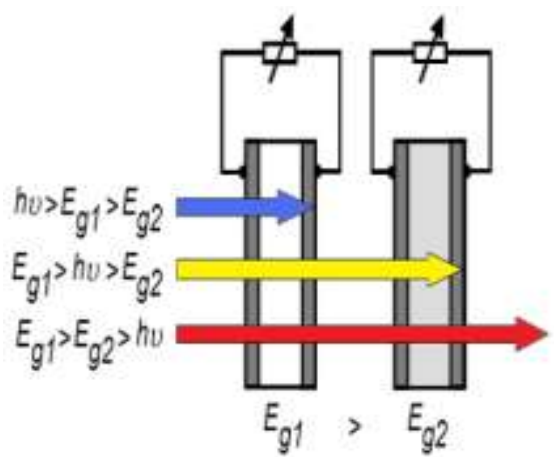

(a)

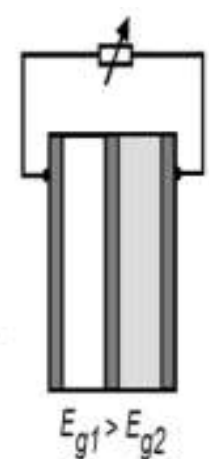

(b)
Fig. 1 a) A stacked tandem solar cell. b) A monolithic tandem solar cell [21].

In the case of solar cells with a single junction, thermalization occurs. This phenomenon occurs when higher energy photons are absorbed, but as heat, part of the energy is lost (excess energy). One of the main targets for the expected techniques was to minimize thermalization leakage by applying a form of a multijunction. A tandem solar cell was created in a shape of a combination between the bottom of a narrow band gap cell and a wide band gap cell. As shown in Fig. (1) in tandem devices, photons with high energy are reaped by a wide band gap top cell while a small band gap bottom cell absorbs low-energy photons uncaptured by the wide band gap top. Tandem solar cells could be defined as multi-junction photovoltaic devices with two sub-cells that are accumulated together or stacked to serve in a stronger broader solar absorption [6].

Tandem solar cells surmount single-cell devices in many qualities. Different sorts of tandem solar cells have been examined: organic/organic (small molecules $[7,8]$, polymers $[9,10])$ solar cells, dye-sensitized solar cells (DSSC) [11-14], inorganic/inorganic (amorphous and microcrystalline silicon (a-Si/ $\mu \mathrm{c}-\mathrm{Si})[15,16])$ solar cells, and hybrid (DSSC/ $\mathrm{Cu}$ (In, Ga) $\mathrm{Se}_{2},[17,18]$ DSSC/Si [19, 20]) solar cells.

This review aims at presenting a complete survey of perovskite-based multi-junction PVs. Expressing the steps of its development and conveying a general description of the field today and its perspective. The article analyzed the different patterns of multi-junction cells. It presented a halide perovskite attempt for multijunction cell personification and evaluated the actual condition of the art. The review discussed the limits of these devices theoretically with some illustrating models and finally by facing the challenges that stick around this technology.

\section{Tandem Architectures for Solar Cells}

Semiconductor layers were set as the most significant elements of a solar cell; they were considered the backbone of such devices. Converting energy of photons into electrical depended mainly upon several various semiconductor substances, each of which had its advantages and defects. When the absorption of light occurs, photons energies are absorbed by electrons in the valance band of the semiconductor substance and jump into the conduction band. Nevertheless, the resulting surplus energy from photons with higher energy than the bandgap gets consumed in thermalization. In this process, the energetic electrons are eased to the edge of the conduction band leading to a decline in the device efficiency. To avoid such conventional restraints in PV performance, tandem (two-junction) or multi-junction (two or more junctions) solar cells applied various layers of absorber with different bandgap. The efficiency limit for the single-junction solar cells has reached $33.7 \%$, whereas the potential efficiency for the double-junction tandems theoretically reaches $46.1 \%$. In the design of perovskite tandems, three basic architectures were put into account: mechanically stacked (Fig. 2(A)), monolithically integrated (Fig. 2(B)), and spectrally split.

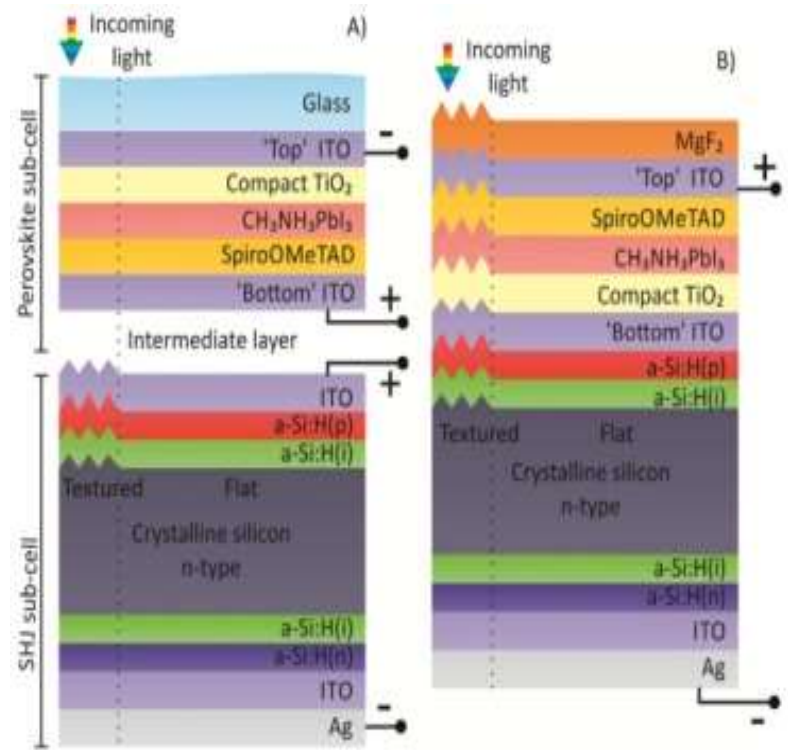

Fig. 2 Architectures of (4T) stacked (A), (2T) monolithically integrated (B) $\mathrm{CH}_{3} \mathrm{NH}_{3} \mathrm{PbI}_{3}$ perovskite / silicon tandem solar cells [22].

Flexibility in designing and processing is one of the prominent characteristics of mechanically stacked tandems. The pre-developed single-junction design 
considerations are applied to the tandem by different fabrication. The top and bottom strings of the cell in the module can be manipulated to match the voltage or the current among the strings to permit formation as well as installation for the simple module [23].

The merit of monolithically integrated tandem was its efficiency and the low affordable expenses of its industry. However, the mechanically stacked tandem needs four electrodes, three of which had to be transparent. Still, two electrodes were demanded in the case of monolithically integrated tandem, and only just one had to be transparent. The monolithically integrated tandem could be classified later depending on the intermediate layer that helped connect the two sub-cells electrically. This middle layer could be either a band-to-band tunnel junction or a layer that was intermingled via a thin metal or a transparent electrode to perform as a recombination site [24, 25]. A proven option of Band-to-band tunnel junctions is used in III$\mathrm{V}$ tandem solar cells [26]. Spectral splitting [27] gathered both of the good characteristics of monolithically integrated and mechanically stacked tandems, but the way of how to produce it widely through industry was ambiguous. This architecture was only attainable in high-concentrator systems because of the high cost of the dichroic mirrors and the physical geometry of the spectrally split system.

\section{Bandgap Tunability of Perovskites}

As we mentioned before, perovskite solar cells (PSCs) occupied most of the scientific thought recently owing to their low expenses, bandgap tunability [2831], high absorption coefficient [32] and high carrier diffusion lengths [33]. As observed, power conversion efficiency (PCE) of PSCs had raised quickly from 3.8\% in 2009 [34] to a basic steady-state rate of $22.7 \%$ in April 2018 [35,36]. A favour returned to a Gustav Rose who discovered calcium titanate $\left(\mathrm{CaTiO}_{3}\right)$ in 1839 in the Ural Mountains of Russia and named after Russian mineralogist L. A. Perovski (1792-1856) [37]. It was regarded as the core perovskite, and all the materials that resembled the kind of the crystal component as that of $\mathrm{CaTiO}_{3}$ were called the perovskite materials (structure). The distinct physical qualities of perovskite substances obtained great attention in optoelectronic and photovoltaic applications. For metal halide perovskites, that mostly focused on methylammonium lead halide $\left(\mathrm{CH}_{3} \mathrm{NH}_{3} \mathrm{PbX}_{3}\right)$ and cesium lead halide $\left(\mathrm{CsPbX}_{3}\right)$ perovskites were the most common models. Halide perovskite structure had early occurred at $\mathrm{CsPbX}_{3}$ in 1958. Consequently, research and discussions began in the 1970 s on methylammoniumbased perovskites, and those substances were highlighted as a result of the new beneficial optical and electrical qualities. Such substances were investigated for the sake of field-effect transistor (FET) and thinfilm light-emitting diode (LED) applications. The first discovery in methylammonium halide $\left(\mathrm{MAX}_{3}\right)$ perovskites existed into action as found in lightabsorbing materials through the photovoltaic appliance by Miyasaka et al. [38]. The perovskite materials are also used on a large scale in waveguides, nanolasers, and photodetectors [39-43]. The condition of perovskite art materials consisted of $\mathrm{ABX}_{3}\left(\mathrm{AMX}_{3}\right)$ formula for the chemical composition, where $\mathrm{X}$ indicates anion, usually halogens or oxides. At the same time, A larger than that of B and both of them are cations. Various patterns of perovskite materials as halide perovskite $\left(\mathrm{ABX}_{3}\right)$ and chalcogenide perovskite $\left(\mathrm{AMO}_{3}\right)$ were ranked again as organometal halide and alkali halide. $\mathrm{A}$ is a tiny organic or inorganic cation with a +1 charge as cesium (Cs), methylammonium (MA) or formamidinium (FA). Tin Sn, germanium Ge or lead $\mathrm{Pb}$ are examples for $\mathrm{B}$ which $\mathrm{B}$ refers to as a metal cation with a +2 charge.

In contrast, iodide IX, chloride $\mathrm{Cl}$, and bromide $\mathrm{Br}$ are other examples for $\mathrm{X}$ and $\mathrm{X}$ halide anion with $\mathrm{a}-1$ charge, as demonstrated in Fig. (3). It was observed that by changing the proportion between $\mathrm{I}$ and $\mathrm{Br}$ in $\operatorname{MAPb}\left(I_{x} B r_{1-x}\right)_{3}$, the bandgap of the perovskite still could range around 1.6 to $2.3 \mathrm{eV}$. Furthermore, if the formation of $\mathrm{Sn}$ were added, it could be induced into $\sim 1.2 \mathrm{eV}$ [44]. This peculiar privilege of perovskites made them so glamorous for multijunction or tandem solar cells [45].

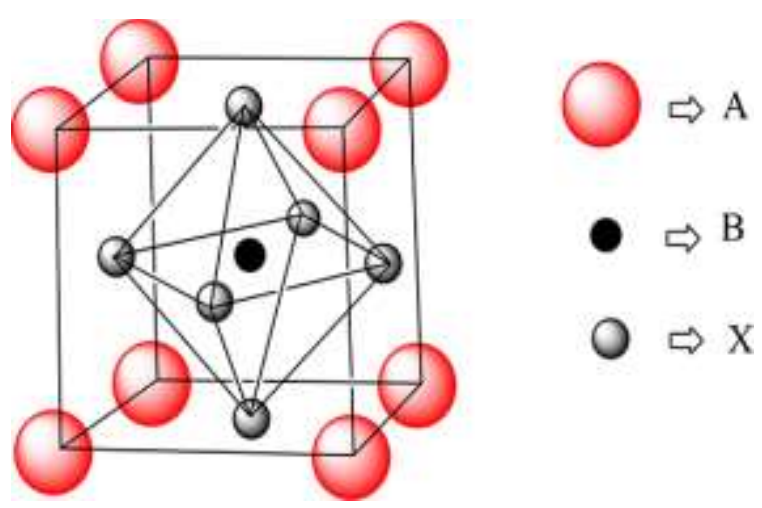

Fig. 3 Crystal perovskite structure [46].

Most digital studies clarified that the main reason behind the bandgap adjustment was embodied in the variable density of states. Such density resulted from the insertion consequences of different anions and cations on the length and angle of the $\mathrm{X}-\mathrm{Pb}-\mathrm{X}$ bond and the different chemical structures [38]. Alloying Snbased and $\mathrm{Pb}$-based perovskites were examined to produce lower bandgaps than neat $\mathrm{Sn}$ or $\mathrm{Pb}$ materials, decreasing into $\sim 1.2 \mathrm{eV}$ [35]. As it was clear, perovskites could lead to the minimum bandgap needed for the narrow-gap sub-cell in a tandem appliance. 
Fig. (4A) describes the design of a double-junction cell by the monolithic technique and the map of related theoretically modeled bandgap/efficiency gained through exploiting realistic material advantages by simulations. Coming to the device architecture, it had a potential efficiency of $>32 \%$ whenever a 1.12 to 1.2 $\mathrm{eV}$ bandgap bottom cell (either perovskite or silicon) and a perovskite top cell with a bandgap of 1.7- to 1.8$\mathrm{eV}$ were merged [45]. Once a triple-junction formulation was converted, there was an expected efficiency rise to $>35 \%$ when applying 1.45 and $1.95 \mathrm{eV}$ perovskite intermediate and top cells above silicon as presented in Fig. (4B). The unique perovskite substance for practical application mixed with silicon (Si) would have a bandgap of about $1.7 \mathrm{eV}$. Nevertheless, it was also observed that the lightinduced phase-segregation mechanism caused the mixed halide perovskites to endure in an obvious way, as first announced by Hoke et al [48].
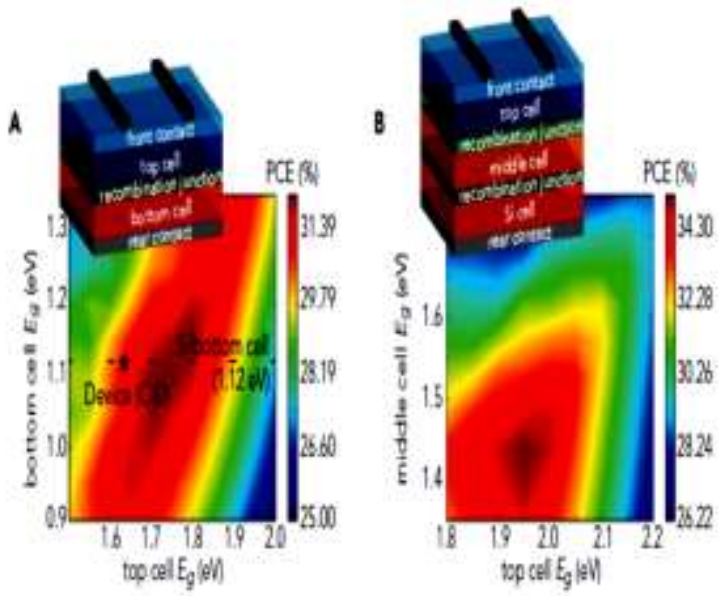

Fig. 4 Configurations of multijunction Perovskite solar Cells: A) Map of theoretical bandgap/power conversion efficiency (PCE) of dual-junction devices, B) Triple-junction perovskite/perovskite/silicon device power conversion efficiencies [47].

This explained that under the process of illumination, materials of mixed iodide-bromide perovskite separated into the bromide-rich and iodiderich area. It was noticed that these zones included more various bandgaps than homogeneous mixed-halide perovskites. In other words, it was told that there was an obvious unsteadiness in the bandgap under illumination as noticed by the photoluminescence valued for a mixed-halide film. Fig. (5) witnessed the change; the fundamental top of photoluminescence to a homogeneous $\mathrm{MAPb}\left(\mathrm{Br}_{0.4} \mathrm{I}_{0.6}\right)_{3}$ films at $1.85 \mathrm{eV}$ was getting lower step by step under illumination the summit $1.68 \mathrm{eV}$ was shown since the I-rich zones photoluminescence was demonstrated. The lowestenergy photoluminescence had significantly marked the bandgap. As a result, it jumped from $1.85 \mathrm{eV}$ to 1.68 $\mathrm{eV}$. Phase segregation caused carriers to be gathered so fast in the minimum-bandgap regions via energy waste and by minimizing the desired open-circuit voltage $\left(\mathrm{V}_{\mathrm{oc}}\right)$.

Photoluminescence measurements grabbed the process of stage segregation: by time a red-shifted peak occurred simultaneously with the hiding of the basic peak. The impact of this photoinduced was metastable and could be converted if the mixed halide perovskite remained in the dark. By illumination experiments, a harmful outcome occurred, the working PSCs sustained by a shortage defect in open-circuit voltage (i.e., $V_{\text {deficit }}$ $=\mathrm{Eg} / \mathrm{q}-\mathrm{V}_{\mathrm{oc}}$, where $\mathrm{q}$ is the primary electron charge ) on a lot of levels standard mixed halide perovskite structures as shown in a modern review by Unger et al [31]. Whenever the voltage was concise, the maximum power conversion efficiencies were assessed and won't be achievable. Thus, the application of mixed-halide perovskites appeared non-perfect in tandem solar cells. Such a defect reflected that photoinduced separation consequence only occurred with mixed halide compositions but not exist with pure iodide or bromide ones. The appearance of sub-bandgap defect or "trap" States led to the mentioned deficiency [48] in the photonic phase separation. The deficit in voltage was a rigid barrier to express high-efficiency perovskite tandem and multijunction solar cells.

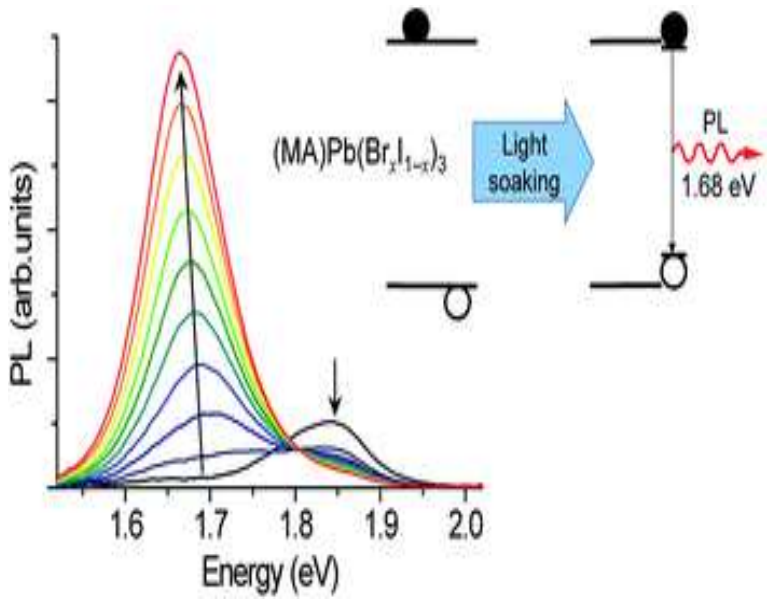

Fig. $5 \mathrm{MAPb}(\mathrm{Br} 0.4 \mathrm{I} 0.6)_{3}$ methylammonium-based mixed-halide perovskite under Photoluminescence (under $457 \mathrm{~nm}$, every 5s) [50].

A detailed investigation as declared in Fig. 6, this following photo-induced degradation mechanism which had blocked the usage of high-bandgap substances inside tandem solar cells, even in the recorded appliances, which chose to use 1.55- to 1.63$\mathrm{eV}$ top perovskite cells on silicon on behalf of higher or more optimal bandgaps [49]. 


\section{Evolution of Perovskite-Based Tandem Solar Cells}

This study presents a deep global perception of the state of the art of perovskite tandem solar cells and discusses all the influential degradation matters involved in this technology. All the eyes were dedicated to perovskite material and how the solar cells performed in high quality for their application. Mixed halide perovskites anticipated its unique advantage for bandgap engineering. Where the bandgap could be ranged between $1.51 \mathrm{eV}$ and $3.0 \mathrm{eV}$ [51-54]. The rise in the absorption coefficient of the mixed halide perovskite returned to the adjusted rate of its bandgap. The idea of tandem technique is based upon a sophisticated method in order to strengthen the efficiency of Si solar to reach a greater percentage of the solar spectrum and transform it into electricity. The mission's target was to concentrate on designing for a type to serve any different perovskite tandem solar cells with the help of SCAPS-1D simulation. The absorption coefficient, the thickness of the absorber layer and dopant concentration acted as the elements which enhanced the solar cell performance. The so modern swift development of photovoltaic and optoelectronic devices returned to the organic-inorganic hybrid halide perovskite. Furthermore, perovskite shared great fame in the common market of the solar cell because of its own ability for simple film deposition via vacuum or solution-based attempts.

When the actual application of the perovskite solar cell concerning its theoretical limitation took place, it was like a sign to go beyond the S-Q limit. Two main problems hindered the single-junction perovskite devices in (1) demonstrating a higher PCE in the below bandgap transmission or (2) thermal relaxation of hot charge carriers. The clue to overcome such an obstacle lay in constructing a tandem junction device that included a bottom cell mainly based on the most common solar cell approaches as silicon $(\mathrm{Si})$ and copper indium gallium selenide (CIGS) and a top cell with a greater bandgap absorber. To improve the stateof-the-art solar cell technology, it was a critical need to a breakthrough using the organic-inorganic hybrid perovskite materials with $\sim 1.55 \mathrm{eV}$ bandgap as the top cell in further.

The efficiency of perovskite solar cells reached more than $20 \%$ using an expensive Spiro-OMeTAD layer [55]. Spiro-OMeTAD/ $\mathrm{MoO}_{\mathrm{x}}$ layer acted as a significant hole selective layer to influence the transparency in May 2015, by Yang (Michael) Yang in his design. Here, the top layer $\left(\mathrm{MoO}_{\mathrm{x}}\right)$ could be regarded as the layer of antireflection, as shown in Fig. 6. Although it was not easy to reach the antireflection stage for all the absorption spectra, the best thickness level of this layer depended basically upon a certain photovoltaic system. In June 2015, Yao-Tsung Hsieh, Yang (Michael) Yang and Qi Chen had effectively presented a multilayer top transparent electrode for hybrid halide perovskite solar cells [56].

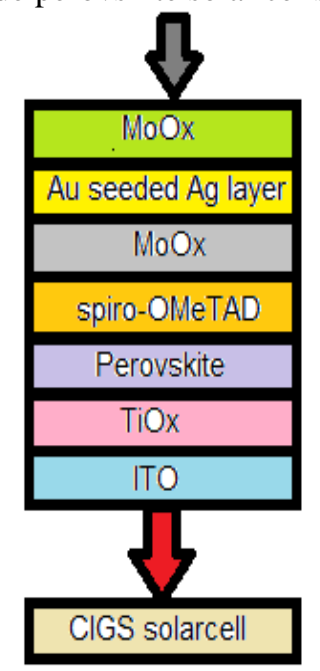

Fig. 6 Device structure, reproduced from [56].

The electrode exploited the traditional dielectric/metal/dielectric structure to formulate a razor-thin gold seeding layer below the silver layer. The gold $(\mathrm{Au})$ seeded silver (Ag) film conveyed developed conductivity and transparency compared to the unpolished $\mathrm{Ag}$ or $\mathrm{Au}$ detected from changing the moistening qualification of the metal deposition. The semi-transparent illuminated solar cell based on perovskite from this multiplayer top electrode reacted efficiently with $11.5 \%$ and displayed approximately no loss of $\mathrm{FF}$ and $\mathrm{V}_{\mathrm{oc}}$ compared to the ordinary device. In the following step, this top perovskite cell was attached to a solution-processed bottom cell CIGS and was designed to be a four-terminal tandem device, pushing with a mixed power conversion efficiency $15.5 \%$. That performance didn't just present an easy way for the transparency of top electrode of perovskite solar cells. Additionally, it reflected awaited path for getting a more refined current solar cell efficiency via the help of tandem perovskite - CIGS solar cell structures.

As Yao-Tsung used copper indium gallium selenide (CIGS) as a bottom cell, other researchers also fabricated another 4-terminal tandem device. As we know the semi-transparent solar cells based on perovskite gained the main focus for their huge area of application as tandem and bifacial solar cells. Nevertheless, the power conversion efficiency for semi-transparent devices remained retarded owing to the non-occurrence of the supposed transparent rear electrode or deposition operation. At that time, a new low-temperature process for the efficiency of semitransparent planar perovskite-based solar cells was declared by Fu and his team in July 2015 [57]. 
In Fig. (7a), an approach of hybrid thermal evaporation-spin coating was applied to insert the fullerene derivative [6,6]-phenyl-C61-butyric acid methyl ester (PCBM) in the appliance composition to promote the existence of high-quality absorber and appliances that are free from hysteresis. They applied a room-temperature radio-frequency magnetron spraying technique to employ transparent rear electrodes from high-mobility hydrogenated indium oxide.
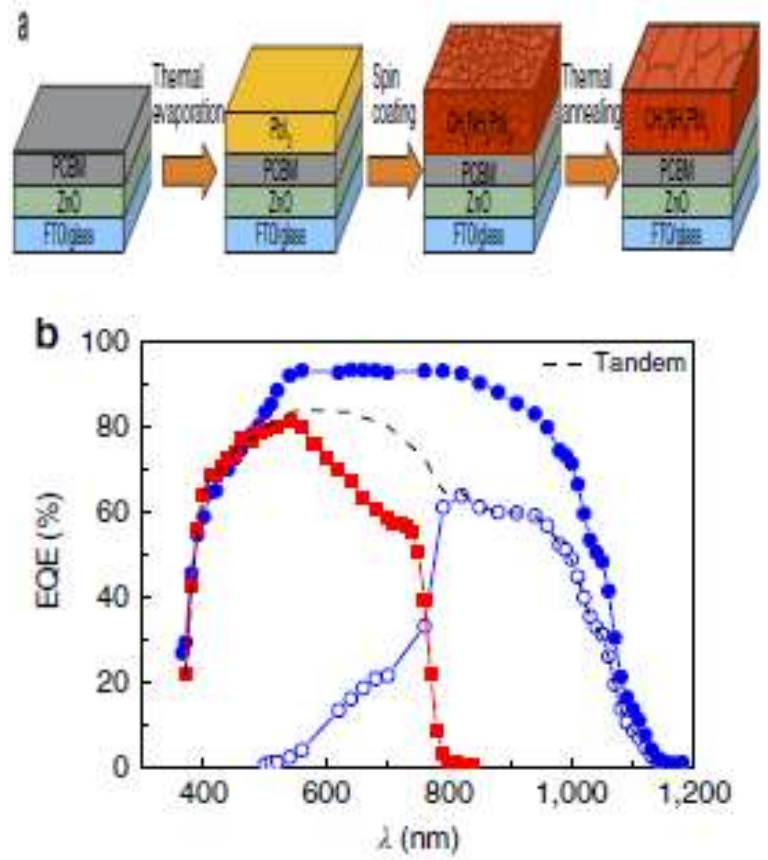

Fig. 7 a) Thermal evaporation/spin coating process for deposition of perovskite layer. b) (EQE) of 4-terminal tandem device (CIGS ( $\bullet$ blue line), CIGS bottom cell ( $\circ$ blue line) and Perovskite top cell (red line)) [57].

Also, due to the advantages of zinc oxide as it has a wide gap with high electron mobility due to its advantages. It is widely used as a hole blocking and electron transport layer through photovoltaic devices such as hybrid, dye-sensitized, organic solar cells, and PSCs [58-60]. They used zinc oxide with a thickness of $100 \mathrm{~nm}$ instead of high-temperature-processed titanium dioxide $\left(\mathrm{TiO}_{2}\right)$. They produced a semi-transparent solar cell with a stable efficiency of $14.2 \%$ as well as $72 \%$ as average transmittance in the close-infrared zone. A significant power improvement was shown with such semi-transparent appliances when they were serving as a bifacial solar cell. After all, they revealed an efficiency of $20.5 \%$ for 4-terminal tandem structure when added to bottom cell (CIGS). Fig. (7b) showed the four-terminal tandem device's External quantum efficiency (EQE) spectra.

In the same month, some researchers used gold as a transparent electrode. To reimburse the wasted thermal energy of silicon solar cells in any tandem devices, perovskite solar cells with transparent contacts should be applied. This offered a way to border languished efficiencies. Nevertheless, perovskite top cells needed high electrical conducted contact layers altogether with perfect and clear transparency. In July 2015, Lang and coworkers directed the issue by carrying out a big graphene area raised by chemical vapor deposition and considered it an extremely transparent electrode in tandem perovskite solar cells. Here the result would be a typical charge accumulated efficiency. The electrical reaction of solar cells with a graphene-based contact came to those of solar cells with leveled golden contacts can be observed in Fig. 8. By far, the optical transmission surpassed that of the actual devices and amounts to $64.3 \%$ under the perovskite bandgap [61]. At last, a four-terminal tandem device described combining a graphene-contacted top wide bandgap $(\mathrm{Eg}=1.6 \mathrm{eV})$ perovskite solar cell and an amorphous/crystalline silicon bottom solar cell $(\mathrm{Eg}=1.12 \mathrm{eV})$.

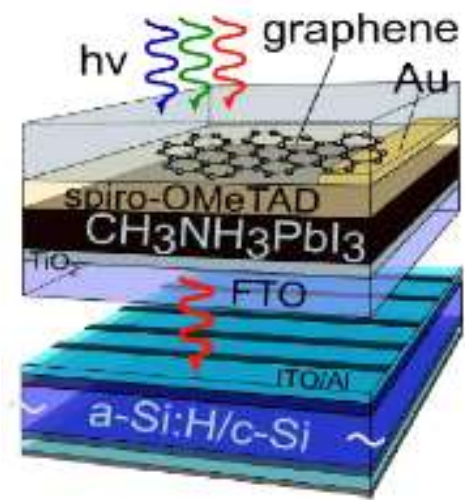

Fig. 8 Structure of 4T tandem solar cell [61].

After one year of Felix Lang's work, Jin Hyuck Heo and Sang Hyuk used a simple lamination technique to fabricate a new $\left(\mathrm{MAPbBr}_{3}-\mathrm{MAPbI}_{3}\right)$ perovskiteperovskite tandem solar cell, In June 2016 [62]. It was possible to apply that easy technique because the conductivity from the support of $\mathrm{Li} / \mathrm{Li}+$ redox shuttle of the thick hole conductor PTAA or P3HT with t-BP and Li-TFSI additives had been strengthened. Hence, the pristine thick hole conductor poly (triaryl amine) (PTAA)or Poly(3-hexylthiophene-2,5-diyl) (P3HT) could not carry the holes adequately to the HTM/PCBM because of the poor conductivity. As shown in Fig. 9, the series tandem solar cell $\mathrm{MAPbBr}_{3}-$ $\mathrm{MAPbI}_{3}$ with $8.3 \mathrm{~mA} \mathrm{~cm}^{-2}, \mathrm{~V}_{\mathrm{oc}}=2.25 \mathrm{~V}, 10.4 \% \eta$ and $56 \%$ FF could be designed by making the $\mathrm{MAPbBr}_{3}$ and $\mathrm{MAPbI}_{3}$ cells as a sandwich. Through investigation, this technique was reported simply as the most beneficial way to manufacture tuned bandgap tandem solar cells of Perovskite-Perovskite, Perovskite-Si and Perovskite-CIGS and they were the ready procedure to provide with solar fuels. 


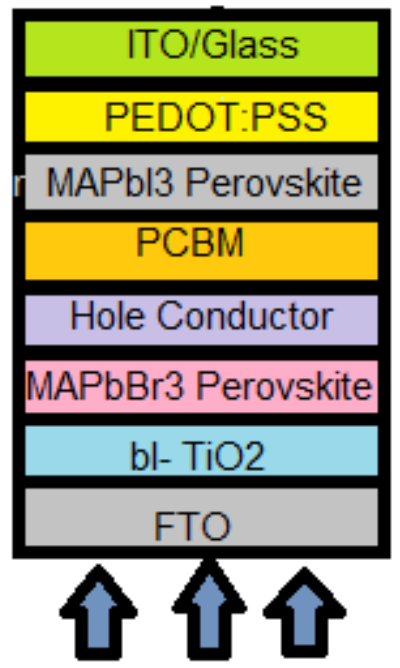

Fig. 9 Perovskite-perovskite $\left(\mathrm{MAPbBr}_{3}-\mathrm{MAPbI}_{3}\right)$ tandem solar cell, reproduced from [62].

In July 2016, Jeremie Werner and his co-workers conveyed an efficiency of $14.5 \%$ on a $1 \mathrm{~cm}^{2}$ nearinfrared transparent perovskite solar cell within contrast to $16.4 \%$ on $0.25 \mathrm{~cm}^{2}$. Four-terminal tandem calculations with $25.2 \%$ steady-state efficiency on a $0.25 \mathrm{~cm}^{2}$ top cell were displayed via mechanically stacking these cells with heterojunction silicon cells. The advanced top cell processing systems served $20.5 \%$ efficiency with $1.43 \mathrm{~cm}^{2}$ great monolithic perovskite/silicon tandem heterojunction solar cells. It produced a rear-side layered bottom cell to add for its near-infrared spectral response [56]. Briefly, all scientists in that field tried to differentiate the formation of tandem to introduce efficiency-limiting factors and investigate extra performance attempts. Fig. 14: 4terminal mechanically stacked tandem: NIR transparent perovskite top cell/silicon heterojunction bottom cells. In July 2016, Jeremie Werner and his coworkers conveyed an efficiency of $14.5 \%$ on $1 \mathrm{~cm}^{2}$ near-infrared transparent perovskite solar cells compared to $16.4 \%$ on $0.25 \mathrm{~cm}^{2}$. Four-terminal tandem calculations with $25.2 \%$ steady-state efficiency on a $0.25 \mathrm{~cm}^{2}$ top cell were displayed via mechanically stacking these cells with heterojunction silicon cells.

The structure below (Fig. 10) showed four-terminal tandem calculations with $25.2 \%$ SteadyState efficiency for a $0.25 \mathrm{~cm}^{2}$ top cell were displayed via mechanically stacking these cells with heterojunction silicon cells. The advanced top cell processing systems served in the industry of $20.5 \%$ efficient with $1.43 \mathrm{~cm}^{2}$ great monolithic perovskite/silicon tandem heterojunction solar cells [63]. It produced a rear-side layered bottom cell to add for its near-infrared spectral response. Briefly, all researchers in that field tried to explore different ways of producing tandems to eliminate efficiency-limiting factors and investigate higher performance methods. After a few months, two and four-terminal (perovskite-perovskite) tandem solar cells with matched bandgaps were offered by Giles E. Eperon, Tomas Leijtens, and Kevin A. Bush in Nov 2016. Their breakthrough was the improvement of perovskite with a bandgap of $1.2 \mathrm{ev}$ for absorption under infrared, $\mathrm{FA}_{0.75} \mathrm{Cs}_{0.25} \mathrm{Sn}_{0.5} \mathrm{~Pb}_{0.5} \mathrm{I}_{3}$, which could anticipate $14.8 \%$ efficiency. By controlling the substance via adding a wider bandgap $\mathrm{FA}_{0.83} \mathrm{Cs}_{0.17} \mathrm{~Pb}\left(\mathrm{I}_{0.5} \mathrm{Br}_{0.5}\right)_{3}$ substance, $17.0 \%$ monolithic 2-terminal tandem efficiencies with open-circuit voltage $>1.65$ volts were completely achieved. Moreover, stacked four-terminal tandem cells were also mechanically made and obtained $20.3 \%$ efficiency [64].

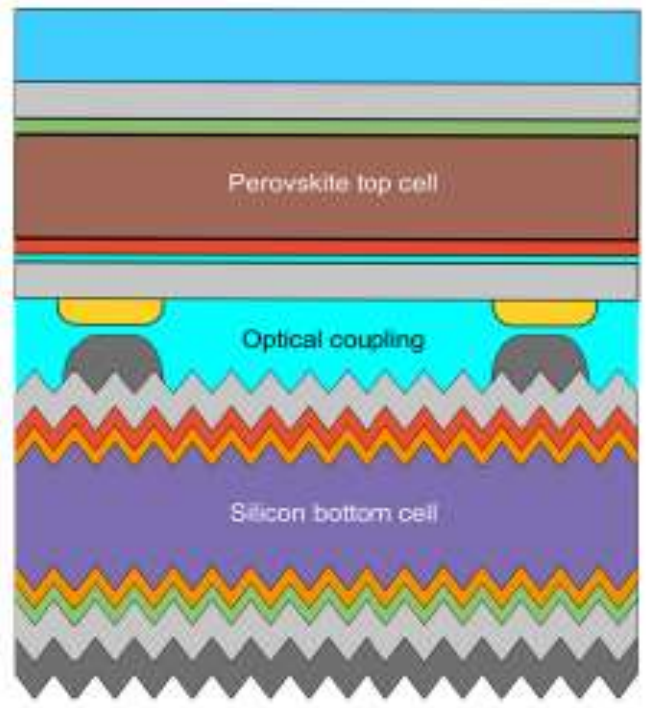

Fig. 10 4-terminal mechanically stacked tandem: NIR transparent perovskite top cell/silicon heterojunction bottom cell [63].

It was mostly detected that the perovskite cells of infrared absorbing provided incredibly excellent thermal and atmospheric stability for Sn-based perovskites. In Dec 2017, Mahedi Habib and his coworkers focused on the low-cost solar cell with high efficiency by choosing Si instead of GaAs whose cost was incredibly high for worldly matters to making tandem solar cell (c-Si solar cell with a perovskite solar cell). They had created a conceptual scheme for giving simplified 2-terminal perovskite/c-Si tandem solar cells (Fig. 11). By extermination, the advanced model witnessed that the efficiency could be developed by making the tandem including Perovskite and Si. The Perovskite-Si tandem solar cell registered for the highest efficiency reaction of $31.8547 \%, \mathrm{~J}_{\mathrm{SC}}=38.2395$ $\mathrm{mA} / \mathrm{cm}^{2}, \mathrm{~V}_{\mathrm{oc}}=0.9995 \mathrm{~V}$ and $\mathrm{FF}=83.3487 \%$ [49]. Perovskite optimum thickness layer $\left(\mathrm{CH}_{3} \mathrm{NH}_{3} \mathrm{PbI}_{3}\right)$ was accounted to be $6 \mu \mathrm{m}$ for the perovskite solar cells because a better electrical quality could be appeared 
and displayed at that degree. Furthermore, the donor concentration of $\mathrm{CH}_{3} \mathrm{NH}_{3} \mathrm{PbI}_{3}$ was the most initial factor for the Perovskite-Si tandem. The Current matching situation had also been accomplished by diverting these parameters. There was a prominent impact parameter of the transport layer on the behavior of tandem cells and on the options of explaining and designing low cost, high efficiency with stability tandem solar cells. The characteristics of this cell architecture were embodied in the highest efficiency of silicon-based single-junction; high potential inferred through the thin-film emitters structure. Such qualities were shown in higher $\mathrm{V}_{\mathrm{OC}}$ values than traditional Crystalline silicon (C-Si) based homojunction. One of the displayed advantages was any voltage gain is due to the two stacked cells.

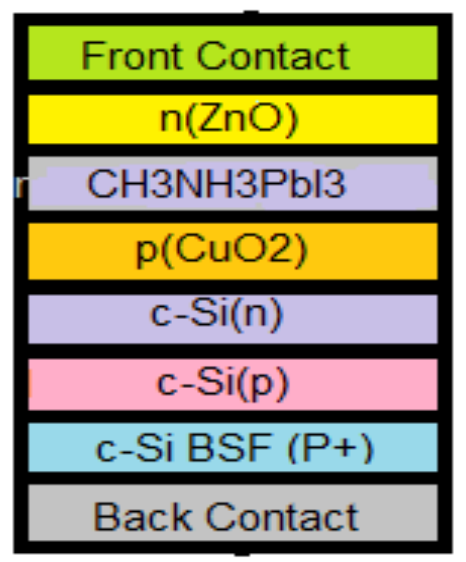

Fig. 11 Perovskite/Si tandem cell reproduced from [49].

Giles E. Eperon used tin-lead perovskite (FA0.75Cs0.25Sn0.5Pb0.5I3) as a low gap perovskite material in 2016 Leijtens, Tomas and Prasanna used the same material in Aug 2018. They revealed the production of monolithic all-perovskite tandem solar cells with a $19.1 \%$ conversion power efficiency, as shown in Fig 12. The cells also displayed the tin-lead perovskite's more developed operational, atmospheric and thermal stability, helping as a low gap absorber. Thick and uniform tin-lead perovskites were constructed via a lane, allowing the two-terminal tandem to gain $80 \%$ of external quantum efficiencies in the near-infrared. All that was to achieve a strong current density that coped with the two-terminal tandem through post-processing to the as-deposited tinlead perovskite films with the help of methylammonium chloride vapor. In their experiment, grain sizes were raised to over a micron, and the opencircuit voltage of the solar cell was fostered and fill factor.

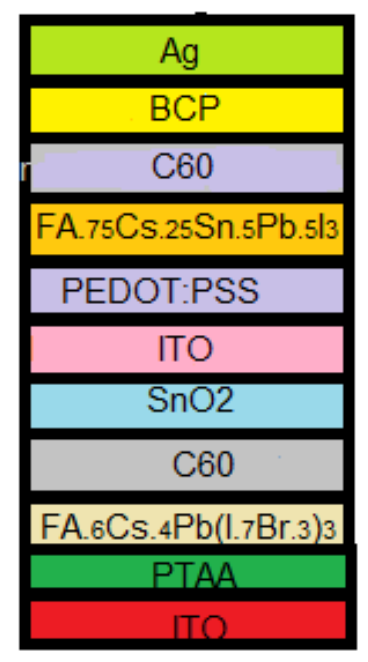

Fig. $12 \mathrm{FA}_{0.75} \mathrm{Cs}_{0.25} \mathrm{Sn}_{0.5} \mathrm{~Pb}_{0.5} \mathrm{I}_{3}$ perovskite tandem solar cell structure, reproduced from [65].

To date, any tin-lead perovskite solar cells, which applied this system, showed the steadiest operation at the summit point of energy under the sunlight of any stated narrow bandgap perovskite solar cell. After 150 hours at $85 \mathrm{C}$ in air, they showed that the full performance of unencapsulated tin-lead perovskite solar cell was maintained. It was considered to be better than that observed before. The process is planned to obtain perovskite tandem solar cells with high efficiency while getting thermal and operational stability [65].

In Nov 2018, Md. Masud Rana and some researchers had the same concept that was put forward in 2017 but with some differences. Three kinds of solar cell structures were planned $\{a\}$ c-Si solar cell, $\{b\} \mathrm{Si}-$ mixed halide perovskite tandem solar cell without $\mathrm{TiO}_{2}$ and $\{\mathrm{c}\}$ with $\mathrm{TiO}_{2}$. Mixed halide perovskite was used on behalf of halide perovskite as a top wide-bandgap absorber layer and c-Si as a bottom narrow bandgap absorber layer. So, many solar spectrums were covered by the cell and its efficiency was developed. The efficiency was to be compared closely to the Si solar cell and other alternatives. The presence of Si-mixed halide perovskite tandem cell was followed using the SCAPS-1D simulator. The sample determined that efficiency could be getting better by designing a tandem solar cell. Factors like doping concentration, thickness, and absorption coefficient had a significant effect on cell performance. The doping concentration and optimum thickness of $\mathrm{CH}_{3} \mathrm{NH}_{3} \mathrm{PbICl}_{2}$ were $1017 \mathrm{~cm}^{-3}$ and $300 \mathrm{~nm}$. The highest performance was measured for tandem solar cell $\left(\mathrm{Si}-\mathrm{CH}_{3} \mathrm{NH}_{3} \mathrm{PbICl}_{2}\right)$ is $\mathrm{J}_{\mathrm{SC}}$ $=43.0069 \mathrm{~mA} / \mathrm{cm}^{2}, \mathrm{~V}_{\mathrm{OC}}=0.7370 \mathrm{~V}, \eta=26.99 \%$ and $\mathrm{FF}=85.14 \%$ [66]. Despite the importance of $\mathrm{TiO}_{2}$ as a 
carrier layer for electrons, when they compared the performance of two tandem cells, it was noted that the performance of the titanium dioxide-free cell was better than the cell containing titanium dioxide due to the high absorption of the perovskite layer, as it can act as electron and hole transporter. But we still need a solution to make the energy conversion efficiency higher. Therefore, some researchers have resorted to using $\mathrm{TiO}_{2}$ nanotube (TD-NT) as an electron transport layer. Under the same conditions, they found that PSC based on TD-NT has a higher PCE (19.14\%) compared to PSC that used $\mathrm{TiO}_{2}$ nanoparticles (TD-NP) (17.18\%) [67]. It was somehow essential to manage photons to realize Perovskite-Si tandem solar cells with power conversion efficiencies that jump over the records of single-junction solar cells. That was assured by the last published record power conversion efficiency of Perovskite-Si tandem solar cells. The aim was reached for an electrically and optically rough solar cell. Mohammad Ismail, in Nov 2018, proposed an alternative solar cell design. It was electrically flat mingled with slightly rough interfaces. The presented design tried to mix the value of reaching high shortcircuit currents while repairing the completeness of perovskite films processed on planar surfaces or substrates. One of the targets was to reach for a high fill factor and open-circuit voltage. The resulting short circuit current was electrically flat, although optically rough solar cells and higher than the short circuit current for optically and electrically flat solar cells. One of the advantages of perovskite material was its low refractive index, unlike inorganic solar materials such as silicon, which had a high refractive index. For textured interfaces in thin-single junction perovskite solar cells, the obtained short-circuit current was caused by a mixture of light trapping and improved light coupling, whereas, for thick perovskite solar cells, what mainly got was caused by improved light coupling. The construction of the offered singlejunction perovskite solar cell rose to $90 \%$ of its potential maximum short-circuit current by applying just 300-400 $\mathrm{nm}$ of thickness [68]. The proposed Perovskite-Si solar cell displayed the matched shortcircuit current density $\left(j_{\mathrm{sc}}\right)$ of $20 \mathrm{~mA} / \mathrm{cm}^{2}$, which permitted inquiring tandem solar cells with power conversion of $30 \%$.

Maximizing Perovskite silicon tandem solar cells was the promising up-to-date technology to end up the efficiency limit of silicon solar cells. Although it was announced that the highest tandem efficiencies were for the inverted $p$-i-n structure, single-junction perovskite solar cells with high efficiency were generally manufactured in the ordinary n-i-p architecture. In June 2019, mixed cation mixed halide high bandgap absorber in regular $n-i-p$ perovskite solar cells familiar to tandem solar cells. They were investigated by inversing engineering.

The open-circuit voltage $\left(\mathrm{V}_{\mathrm{oc}}\right)$ was improved to over voltage $1.12 \mathrm{~V}$ by using a passivating electron contact by Patricia S.C. Schulze and Alexander J. Bett. The optimized top perovskite solar cell was applied in a monolithic Perovskite-Si tandem device with a silicon bottom heterojunction cell. Although there are many alternatives, $\mathrm{TiO}_{2}$ is considered the best type of electron transparent layer and it has achieved the best results in the performance of the PSCs $[69,70]$. Thus, more research must be conducted on $\mathrm{TiO}_{2}$ to enhance the PCE of PSCs. So, they used the first compact $\mathrm{TiO}_{2}$ layer (20 nm) by electron beam evaporation. Then, a mesoporous $\mathrm{TiO}_{2}$ scaffold was layered by spin coating. It permitted for voltages up to $\sim 0.725 \mathrm{~V}$. The tandem solar cells had efficiencies $>20 \%$ with an active area of $0.25 \mathrm{~cm}^{2}$ reached high points open-circuit voltages $\left(\mathrm{V}_{\mathrm{oc}}\right)$ of up to $1.85 \mathrm{~V}$ [71]. Explaining the perovskite absorber by physically solved photoluminescence measurements conveyed stable and homogenous radiation at $\sim 1.7 \mathrm{eV}$, an optimal value for tandem devices with $\mathrm{Si}$. The tandem solar cells were restricted because of the low current. A spectrometric advantage declared that the perovskite-based solar cell was current limiting which a thicker perovskite absorber could develop.

Afsal Manekkathodi, in Oct. 2019, traced a clue that followed up solution-processed hybrid tandem photovoltaic appliances. It happened by mixing two arising photo-absorbing substances, CQDs (Colloidal quantum dots) and perovskites. The 4T tandem solar cell won $20.2 \%$ stabilized efficiency built on a CQD back and perovskite front cells. Perovskite solar cells contained an ultrathin dielectric-metal-dielectric layer provided semi-transparent solar cells with $18 \%$ stabilized power conversion efficiencies for the top perfect cells. PCEs were observed as one of the strongest semi-transparent solar cells and the suitable cells to represent the front cell in 4-terminal tandem appliances. This dielectric-metal dielectric transparent conducting electrode (DMDTCE), which included a sandwich of ultrathin $\mathrm{Au} / \mathrm{Ag}$ metal film among insulating $\mathrm{MoO}_{3}$ layers, had an obvious reliant wavelength conveying as a maximum IR transmittance for the tandem configuration. But for, The CQD solar cell carried out a PCE of $11.3 \%$ under raw solar lightening and $2.6 \%$ of PCE when it acted as the back cell behind the front cell perovskite. 


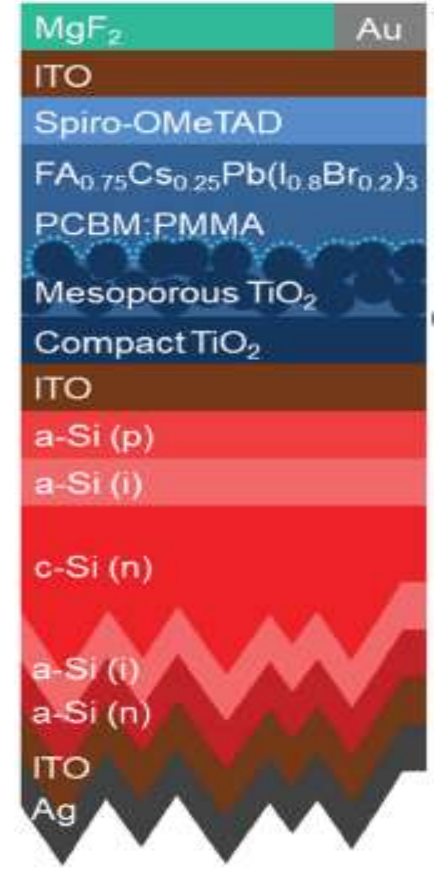

Fig. 13 Structure of a perovskite silicon tandem solar cell [71].

The conclusion discussed perovskite and CQD solar cells as a future mingling for solution-processed tandem solar cells for the coming era of photovoltaic technologies [72]. The idea of tandem solar cells by sandwiched materials is becoming more and more known. As Felix Lang used gold as a transparent electrode in 2015, some researchers used a nanomesh of gold for the same purpose after five years.

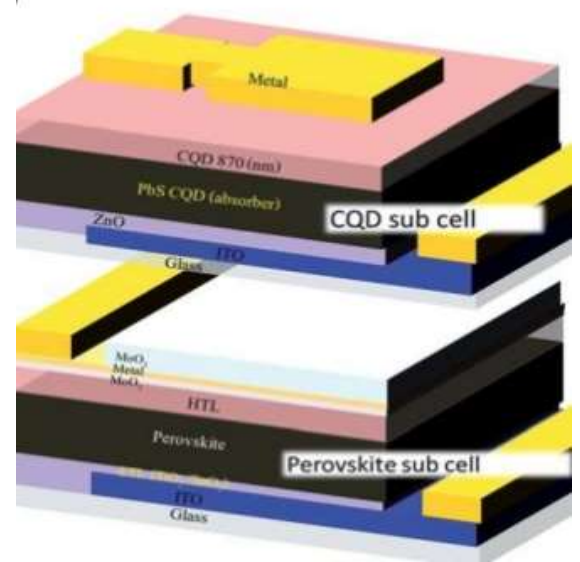

Fig. 14 Schematic of a 4-Terminal tandem solar cell device (Perovskite- CQD tandem cell) [72].

In June 2020, Shengnan Zuo and his co-workers inserted a sandwiched nanomesh of gold among the layers of $\mathrm{MoO}_{3}$, which performed as a transparent electrode. The huge surface strain of $\mathrm{MoO}_{3}$ significantly enhanced hydrophilicity for gold.
Frank-van der Merwe's growth was to generate an ultrathin golden nanomesh layer that guaranteed both high conductivity and unique optical transparency, which were the core of a tandem/multijunction solar cell. The more the light was transmitted, the more the top $\mathrm{MoO}_{3}$ layer minimized the reflection at the golden layer. Consequently, the semi-transparent perovskite cell reflected an $18.3 \%$ efficiency, regarded as the top type of appliance. Via mechanically stacked technique, when the semi-transparent perovskite appliance was stacked with $23.3 \%$ PCE of a heterojunction silicon solar cell, it achieved a mixed efficiency of $27.0 \%$, greater than those of the sub-cells [73]. This breakthrough in increasing the efficiency of semitransparent and tandem/multijunction devices could serve to exceed the Shockley-Queisser (SQ) limit.

In 2020, Wenjie Li showed a monolithically integrated solar flow battery (SFB) appliance based on perovskite-Si tandem solar cells that configurated main achievements in several directions, including SPUR, SOEE, device lifetime, and capacity utilization rate, without compromising the low cost of its industry. The perovskite $\left(\mathrm{FAPbI}_{3}\right)_{0.83}\left(\mathrm{MAPbBr}_{3}\right)_{0.17} /$ silicon tandem solar cell was reasonably planned specifically for aqueous organic SFBs. It was designed to deliver high efficiency and provide low expenses effective perovskite-compatible method of manufacturing the electrolyte contact for Si bottom cell also allowed better steadiness and device lifetime. In addition, the researcher had improved a numerical calculation method. It led us to the right choice of BTMAP$\mathrm{Vi} / \mathrm{NMe}$-TEMPO redox couples to match the Perovskite-Si cells and to reach a high SPUR and SOEE. Furthermore, it concentrated on the insight idea of the integrated solar storage technologies with voltage matching principles in general. The amazing results investigated a basic trend towards a practical technique of using integrated solar flow batteries SFBs for solar home systems and other divided solar power generation plus being a source of applications [74].

\section{Conclusion}

To conclude, multi-junction solar cells with integrated perovskites have risen as a challenging area of research. It represents swift progress and has a great economic concern. The best cells have already become more efficient than single-junction perovskite solar cells. The cells were getting very near to the best silicon cells, though there were just a few years of focused research efforts compared to silicon for many decades. The outstanding efficiencies and adjustable bandgaps 
of perovskite semiconductors made them ideal participants for using multi-junction architectures, even as hybrid cells, including more established technologies or all-perovskite multi-junction cells. The deepest marketing view of the hybrid tandem perspective is that it permitted perovskites to potentially leverage an accomplished technology to control the competitive photovoltaic PV market. Through investigation, hybrid tandems would likely be the most frequently used perovskite modules to join the market. They would significantly be a push to $\mathrm{Si}$ modules via supporting with aimed improvements for the minimal added expense and adjusting the scaled production of the $\mathrm{Si}$ manufacture. As soon as the large-scale fabrication of perovskites had been accomplished and the eternal problems had been solved, all-perovskite tandem cells and multi-junction cells became the most impressive options and even a more inexpensive technology.

\section{References}

[1] Renewables 2016 Global Status Report. Renewable Energy Policy Network for the 21st Century 2016, 1-272.

[2] International Energy Agency (IEA), Technology Roadmap - Solar Photovoltaic Energy 2010, 2010.

[3] D. Almond and C. Bowen, An Explanation of the Photoinduced Giant Dielectric Constant of Lead Halide Perovskite Solar Cells. The Journal of Physical Chemistry Letters, 6 (2015) 1736-1740.

[4] B. Ezealigo, A. Nwanya, S. Ezugwu, S. Offiah, D. Obi, R. Osuji, R. Bucher, M. Maaza, P. Ejikeme and F. Ezema, Method to control the optical properties: Band gap energy of mixed halide Organolead perovskites. Arabian Journal of Chemistry, 13 (2020) 988-997. https://doi.org/10.1016/j.arabjc.2017.09.002

[5] V. S. Sivaram, S. D. Stranks, and H. J. Snaith, Perovskite solar cells join the major league. Science, 350 (2015) 917-917.

[6] L. J. Schmidt, Tracking down the truth of Perovskite in $38^{\text {th }}$ Rochester Mineralogical Symp. Program Notes, (2011) 31-32.

[7] R. Swanson, Approaching the $29 \%$ limit efficiency of silicon solar cells. in Thirty-first IEEE Photovoltaic Specialists Conference, 2005.

[8] J. Y. Kim, K. Lee, N. E. Coates, D. Moses, T. Q. Nquyen, Efficient Tandem Polymer Solar Cells Fabricated by All-Solution Processing. Science, 317 (2007) 222-225.

[9] M. Riede, C. Uhrich, J. Widmer, R. Timmreck, D. Wynands, G. Schwartz, W. M. Gnehr, D. Hildebrandt, A. Weiss, J. Hwang, S. Sundarraj, P.
Erk, M. Pfeiffer and K. Leo, Efficient Organic Tandem Solar Cells based on Small Molecules. Adv. Funct. Mater., 21(2011) 3019. https://doi.org/10.1002/adfm.201002760

[10] A. Mishra and P. Bauerle, Small Molecule Organic Semiconductors on the Move: Promises for Future Solar Energy Technology. Chem. Int. Ed, 51(2012)

2020. https://doi.org/10.1002/anie.201102326

[11] L. Dou, J. You, J. Yang, C. C. Chen, Y. He, S. Murase, T. Moriarty, K. Emery, G. Li and Y. Yang, Tandem polymer solar cells featuring a spectrally matched low-bandgap polymer. Nat. Photon, 6 (2012) 180-185.

[12] Z. Tan, W. Zhang, Z. Zhang, D. Qian, Y. Huang, J. Hou, Y. Li, High-Performance Inverted Polymer Solar Cells with Solution-Processed Titanium Chelate as Electron-Collecting Layer on ITO Electrode. Adv. Mater, 24 (2012) 1476. https://doi.org/10.1002/adma.201104863

[13] A. Nattestad, A. J. Mozer, M. K. R. Fischer, Y. B. Cheng, A. Mishra, P. Bauerle and U. Bach, Highly efficient photocathodes for dye-sensitized tandem solar cells. Nat. Mater., 9 (2010) 31.

[14] Q. Miao, L. Wu, J. Cui, M. Huang and T. Ma, Highly efficient photocathodes for dye-sensitized tandem solar cells. Adv. Mater, 23(2011) 2764. tandem a-Si/ $\mu$ c-Si solar cells. J. Appl. Phys, 107 (2010) 014507.

[15] J. Upping, A. Bielawny, R. B. Wehrspoh, T. Beckers, R. Carius, U. Rau, S. Fahr, C. Rockstuhl, F. Lederer, M. Kroll, T. Pertsch, L. Steidl and R. Zentel, Three-Dimensional Photonic Crystal Intermediate Reflectors for Enhanced LightTrapping in Tandem Solar Cells. Adv. Mater, 23(2011) 3896. https://doi.org/10.1002/adma.201101419

[16] W. S. Jeong, J. W. Lee, S. Jung, J. H. Yun, N. G. Park, Improvement of dye-sensitized solar cells toward the broader light harvesting of the solar spectrum. Sol. Energy Mater. Sol. Cells, 95 (2011) 3419.

[17] W. L. Wang, H. Lin, J. Zhang, X. Li, A. Yamada, M. Konagai, J. B. Li, Experimental and simulation analysis of the dye sensitized solar cell/Cu (In, Ga) $\mathrm{Se}_{2}$ solar cell tandem structure. Sol. Energy Mater. Sol. Cells, $94 \quad$ (2010) 1753. https://doi.org/10.1016/j.solmat.2010.05.041

[18] G. D. Barber, P. G. Hoertz, S. H. A. Lee, N. M. Abrams, J. Mikulca, T. E. Mallouk, P. Liska, S. M. Zakeeruddin, M. Gratzel, A. H. Baillie and M. A. Green, Utilization of Direct and Diffuse Sunlight in a Dye-Sensitized Solar Cell — Silicon Photovoltaic Hybrid Concentrator System. J. Phys. Chem. Lett, 2(2011) 581. 
[19] S. Hao, J. Wu and Z. Sun, A hybrid tandem solar cell based on hydrogenated amorphous silicon and dye-sensitized $\mathrm{TiO}_{2}$ film. Thin Solid Films ,520 (2012) 2102-2105. https://doi.org/10.1016/j.tsf.2011.08.061

[20] B. Minnaert and P. Veelaert, Guidelines for the Bandgap Combinations and Absorption Windows for Organic Tandem and Triple-Junction Solar Cells. Materials, 5 (2012) 1933-1953. https://doi.org/10.3390/ma5101933

[21] M. Filipič , P. Löper, B. Niesen, S. De Wolf, J. $\mathrm{Krc}^{2}$, C. Ballif and M. Topič, $\mathrm{CH}_{3} \mathrm{NH}_{3} \mathrm{PbI}_{3}$ perovskite / silicon tandem solar cells: characterization based optical simulations. Opt. Express, 23(2015) A263-A278. https://doi.org/10.1364/OE.23.00A263

[22] C.D. Bailie , M.G. Christoforo, J.P. Mailoa , A.R Bowring, E.L. Unger, W.H. Nguyen, J. Burschka, N. Pellet, J.Z. Lee, M. Grtzel, R. Noufi, T. Buonassisi, A. Salleo and M.D. McGehee, Semitransparent perovskite solar cells for tandems with silicon and CIGS广. Energy Environ. Sci, 8 (2015) 956.

[23] J.P. Mailoa, C.D. Bailie, E.C. Johlin, E.T. Hoke, A.J. Akey, W.H. Nguyen, M.D. McGehee and T. Buonassisi, A 2-terminal perovskite/silicon multijunction solar cell enabled by a silicon tunnel junction. Appl. Phys. Lett, 106 (2015) 12110.

[24] T. Todorov, T. Gershon, O. Gunawan, C. Sturdevant and S. Guha, Perovskite- kesterite monolithic tandem solar cells with high opencircuit voltage. Appl. Phys. Lett, 105 (2014) 173902.

[25] T. Ameri, G. Dennler, C. Lungenschmied and C.J. Brabec, Organic tandem solar cells: A review. Energy Environ. Sci, 2(2009) 347.

[26] G.J. Bauhuis, P. Mulder and J.J. Shermer, Highefficiency tandem perovskite solar cells. Prog. Photovolt. Res. Appl, 22(2014) 656.

[27] H.J. Snaith, Perovskites: the emergence of a new era for low-cost, high efficiency solar cells. J. Phys. Chem. Lett, 4 (2013) 3623-3630.

[28] S.D. Stranks, G.E. Eperon, G. Grancini, C. Menelaou, M.J.P. Alcocer, T. Leijtens, L.M., Herz, A. Petrozza and H.J. Snaith, Electron-hole diffusion lengths exceeding 1 micrometer in an organometal trihalide perovskite absorber. Science, 342 (2014) 341-344.

[29] S. De Wolf, J. Holovsky, S.-J. Moon, P. Lo per, B. Niesen, M. Ledinsky, F-J. Haug, Y-H. Yum and C. Ballif, Organometallic halide perovskites: sharp optical absorption edge and its relation to photovoltaic performance. J. Phys. Chem. C, 5(2014) 1035-1139.
[30] J.H. Noh, S.H. Im, J.H. Heo, T.N. Mandal, and S.I. Seok, Chemical management for colorful, efficient, and stable inorganicorganic hybrid nanostructured solar cells. Nano Lett, 13 (2013) 1764.

[31] E.L.Unger, L. Kegelmann, K. Suchan, So“ rell, D., L. Korte, and S. Albrecht, Roadmap and roadblocks for the band gap tunability of metal halide perovskites. J. Mater. Chem. A, 5 (2017) 11401-11409.

[32] G.E. Eperon, S.D. Stranks, C. Menelaou, M.B. Johnston, L.M. Herz and H.J. Snaith, Formamidinium lead trihalide: a broadly tunable perovskite for efficient planar heterojunction solar cells. Energy Environ. Sci,7 (2014) 982.

[33] R.J. Sutton, G.E. Eperon, L. Miranda, E.S. Parrott, B.A. Kamino, J.B. Patel, M.T. Ho“ rantner, M.TB., Johnston., A.A., Haghighirad and D.T. Moore, Bandgap-tunable cesium lead halide perovskites with high thermal stability for efficient solar cells. Adv. Energy Mater, 6 (2016) 1502458. https://doi.org/10.1002/aenm.201502458

[34] A. Kojima, K., Teshima, Y., Shirai, and T. Miyasaka, Organometal halide perovskites as visible-light sensitizers for photovoltaic cells. J. Am. Chem. Soc, 131 (2009) 6050-6051.

[35] W.S.Yang, J.H. Noh, N.J, Jeon, Y.C. Kim, S. Ryu, J. Seo, and S.I.Seok ,High performance photovoltaic perovskite layers fabricated through intramolecular exchange. Science, 348(2015) 1234-1237.

[36] H.R. Wenk and A. Bulakh, Minerals:Their Constitution and Origin. NY: Cambridge University Press, 7(2004) 978.

[37] H. J. Snaith, Perovskites: the emergence of a new era for low-cost, high efficiency solar cells. J. Phys. Chem. Lett, 4 (2013) 3623-3630.

[38] E.T. Hoke, Reversible photo induced trap formation in mixed-halide hybrid perovskites for photovoltaics. Chem. Sci, 6 (2015) 613-617.

[39] D.P. McMeekin, A mixed-cation lead mixedhalide perovskite absorber for tandem solar cells. Science, 351 (2016) 151-155.

[40] R.E. Beal, Cesium lead halide perovskites with improved stability for tandem solar cells. J. Phys, Chem. Lett, 7(2016) 746-751. https://doi.org/10.1021/acs.jpclett.6b00002

[41] H.Miao, B.Cheng, Y.Yongbo, B.Yang and H. Jinsong, Stabilized wide bandgap MAPbBr $x \mathrm{I} 3-x$ perovskite by enhanced grain size and improved crystallinity. Adv. Sci. (Weinh), 3 (2016) 1500301. https://doi.org/10.1002/advs.201500301

[42] D.J. Slotcavage, H.J.Karunadasa, M.D. McGehee, M. D, Light-induced phase segregation in halide- 
perovskite absorbers. ACS Energy Lett, 1 (2016) 1199-1205.

\section{https://doi.org/10.1021/acsenergylett.6b00495}

[43] M. I. Hossain, F. H. Alharbi, N. Amin, and N. Tabet, Numerical analysis of hybrid perovskite solar cells using inorganic hole conducting material. 2015 IEEE 42nd Photovolt. Spec. Conf., (2015) 1-4.

[44] F.H. Alharbi, M. I. Hossain, and N. Tabet, Perovskite based solar cells: A milestone towards cheaper PV technology. 3rd Int. Symp. Environ. Friendly Energies Appl EFEA, (2014).

[45] Demic.S, A.Nuri, M.Can, G.Ozbek and M. Karakaya, Recent Progresses in Perovskite Solar Cells. Book; (2017).

[46] G.E.Eperon, M.T.Hörantner and H.J.Snaith, Metal halide perovskite tandem and multiplejunction photovoltaics. Nat. Rev. Chem, 1 (2017) 95.

[47] T.C. Yang, P.Fiala, , Q.Jeangros and C.Ballif, High-Bandgap Perovskite Materials for Multijunction Solar Cells. Joule, 2 (2018) 14211436.

\section{https://doi.org/10.1016/j.joule.2018.05.008}

[48] J.You, Z.Hong and Q.Chen, Low-Temperature Solution-Processed Perovskite Solar Cells with High Efficiency and Flexibility. ACS Nano, 8 (2014) 1674-1680.

https://doi.org/10.1021/nn406020d

[49] N. F. Ramlia, S. Sepeaib, N.F.Rostanc, N. A. Ludind, M. A. Ibrahim, M.A.Teridif \& S. H. Zaidig, Model Development of Monolithic Tandem Silicon Perovskite Solar Cell by SCAPS Simulation. 3rd (EICT), (2017).

[50] E. T. Hoke, D. J. Slotcavage, E. R. Dohner, A. R. Bowring, H. I. Karunadasa and M. D. McGehee, Reversible photo-induced trap formation in mixedhalide hybrid perovskites for photovoltaics. Chem. Sci., 6 (2015) 613-617.

[51] W. Li, A. Furlan, K. H. Hendriks, M. M. Wienk, R. A. J. Janssen, Efficient Tandem and TripleJunction Polymer Solar Cells. J. Am. Chem. Soc, 135 (2015) 5529-5532.

[52] J. Jo, J.-R. Pouliot, D. Wynand, S. D. Collins, J. Y. Kim, T. L. Nguyen, H. Y. Woo, Y. Sun, M. Leclerc and A. J. Heeger, Enhanced Efficiency of Single and Tandem Organic Solar Cells Incorporating a Diketopyrrolopyrrole-Based Low-Bandgap Polymer by Utilizing Combined $\mathrm{ZnO} /$ Polyelectrolyte Electron-Transport Layers. Adv. Mater,25 (2015) 4783.

[53] J. Yang, R. Zhu, Z. Hong, Y. He, A. Kumar, Y. Li and Y. Yang, A Robust Inter-Connecting Layer for Achieving High Performance Tandem Polymer Solar Cells. Adv. Mater, 23 (2011) 3465.
[54] J. Yang, J. You, C.-C. Chen, W.-C. Hsu, H.-R. Tan, X. W. Zhang, Z. Hong and Y. Yang, Recent Progresses in Perovskite Solar Cells. ACS Nano. 5 (2011) 6210.

[55] A. Mei, X. Li, L. Liu, Z. Ku, T. Liu, Y. Rong, M. $\mathrm{Xu}, \mathrm{M} . \mathrm{Hu}, \mathrm{J}$. Chen,Y.Yang, W. Sharmoukh, S. Sajid, P. Cui, J. Ji, S. Dou, D. Wei, H. Huang, W. $\mathrm{Xi}$ and L. Chu, Superior Stability and Efficiency Over 20\% Perovskite Solar Cells Achieved by a Novel Molecularly Engineered RutinAgNPs/Thiophene Copolymer. Adv. Sci, 5 (2018) 1800568. https://doi.org/10.1002/advs.201800568

[56] Y.M. Yang, Y. Yang and Q.Chen, Multilayer transparent top electrode for solution processed perovskite/Cu(In, Ga)(Se,S)2 four terminal tandem solar cells. ACS Nano, 9 (2015) 7714- 7721. https://doi.org/10.1021/acsnano.5b03189

[57] F. Fu, T. Feurer and T.Jager, Low-temperatureprocessed efficient semi-transparent planar perovskite solar cells for bifacial and tandem applications. Nat. Commun, 6 (2015) 8932.

[58] K. Wang, V. Körstgens, D. Yang, N. Hohn, S.V. Roth and P. Müller-Buschbaum, Morphology Control of Low Temperature Fabricated $\mathrm{ZnO}$ Nanostructures for Transparent Active Layers in All Solid-State Dye-Sensitized Solar Cells. J. Mater. Chem. A, 6 (2018) 4405-4415.

[59] K. Wang, S. Xia, W. Cao, N. Hohn, S. Grott, L.P. Kreuzer, M. Schwartzkopf, S.V. Roth and P. Müller-Buschbaum, Comparison of UV Irradiation and Sintering on Mesoporous Spongelike $\mathrm{ZnO}$ Films Prepared from PS-b-P4VP Templated Sol-Gel Synthesis. ACS Appl. Nano Mater, 1 (2018) 7139-7148.

[60] A. M. Elseman, M.S. Selim and Z. Hao, ZnO Nanorods: An Advanced Cathode Buffer Layer for Inverted Perovskite Solar Cells. ACS Appl. Energy Mater, 3, 12, (2020) 11781-11791.

\section{https://doi.org/10.1021/acsaem.0c01945}

[61] N. Liu, L. Wang, F. Xu, J. Wu, T. Song, and Q. Chen, Recent progress in developing monolithic perovskite/Si tandem solar cells. Front. Chem, 8(2020) 603375.

[62] J. H. Heo, S. H. Im, $\mathrm{CH}_{3} \mathrm{NH}_{3} \mathrm{PbBr}_{3}-$ $\mathrm{CH}_{3} \mathrm{NH}_{3} \mathrm{PbI}_{3}$ Perovskite-Perovskite Tandem Solar Cells with Exceeding 2.2 V Open Circuit Voltage. Adv. Mater, 28 (2016) 5121.

[63] J. Werner and L. Barraud, Efficient near-infrared transparent perovskite solar cells enabling direct comparison of 4-terminal and monolithic perovskite/silicon tandem cells. ACS Energy Lett, 1 (2016) 474-480.

[64] G.E. Eperon and K.A. Bush, Perovskiteperovskite tandem photovoltaics with optimized bandgaps. Science, 354 (2016) 861-865. 
[65] T. Leijtens and K.A. Bush, Tin-lead halide perovskites with improved thermal and air stability for efficient all-perovskite tandem solar cells. Sustain. Energy Fuels, 2 (2018) 24502459.

[66] S.M. Al-Rabbi and M.A. Islam, Numerical Simulation and Performance Analysis of SiliconMixed Halide Perovskite Tandem Solar Cell. International Conference on Advancement in Electrical and Electronic Engineering, (2018) 2224.

[67] A. M. Elseman, A. H. Zaki, A. E. Shalan, M. M. Rashad and Q.Song, $\mathrm{TiO}_{2}$ Nanotubes: An Advanced Electron Transport Material for Enhancing the Efficiency and Stability of Perovskite Solar Cells. Ind. Eng. Chem. Res., 59, 41(2020) 18549-18557. https://doi.org/10.1021/acs.iecr.0c03415

[68] W. Qarony, M.I. Hossain, A. Salleo, D. Knipp and Y.H. Tsang, Rough versus planar interfaces: how to maximize the short circuit current of perovskite single and tandem solar cells. Mater. Today, Energy, 11(2019) 106-113.

[69] K. Wang, W. Zhao, J. Liu, J. Niu, Y. Liu, X. Ren, J. Feng, Z. Liu, J. Sun, D. Wang and S. F. Liu, $\mathrm{CO}_{2}$ Plasma-Treated $\mathrm{TiO}_{2}$ Film as an Effective Electron Transport Layer for High-Performance Planar Perovskite Solar Cells. ACS Appl. Mater. Interfaces, 9 (2017) 33989.

[70] A. M. Elseman, C.Xu, Y. Yao, M. Elisabeth, L. Niu, L. Malavasi and Q. L. Song, Electron Transport Materials: Evolution and Case Study for High-Efficiency Perovskite Solar Cells. Sol. RRL, 4(2020) 2000136.

[71] A. J. Bett, P. S. C. Schulze, K. M. Winkler, Ã-Z. S. Kabakli, I. Ketterer, L. E. Mundt, S. K. Reichmuth, G. Siefer, L. Cojocaru, L. Tutsch, M. Bivour, M. Hermle, S. W.Glunz and J. C.Goldschmidt, Monolithic Perovskite Tandem Solar Cells: A Review of the Present Status and Advanced Characterization Methods Toward 30\% Efficiency. Prog. Photovolt. Res. Appl, 28 (2019) 99.

[72] A. Manekkathodi, Solution-processed perovskitecolloidal quantum dot tandem solar cells for photon collection beyond $1000 \mathrm{~nm}$. J. Mater. Chem. A, 7 (2019) 26020-26028.

[73] Z.Wang, X. Zhu, S. Zuo, M. Chen, C. Zhang, C. Wang, X. Ren, Z. Yang, Z. Liu, X. Xu, Q. Chang, S. Yang, F. Meng, Z. Liu, N. Yuan, J. Ding, and D. Yang, 27\%-Efficiency Four-Terminal Perovskite/Silicon Tandem Solar Cells by Sandwiched Gold Nanomesh. Adv. Funct. Mater, 30 (2020) 1908298.
[74] W. Li, J. Zheng, B. Hu, H.-C. Fu, M. Hu, A. Veyssal, Y. Zhao, J.-H. He, T. L. Liu, A. HoBaillie and S. Jin, High-performance solar flow battery powered by a perovskite/silicon tandem solar cell. Nat. Mater., 19 (2020) 1326-1331. 